\title{
Erratum to: In vitro clonal propagation and stable cryopreservation system for Platycladus orientalis via somatic embryogenesis
}

\author{
Chang-Ho Ahn ${ }^{1} \cdot$ Yong-Eui Choi $^{1}$
}

Published online: 22 September 2017

(c) Springer Science+Business Media B.V. 2017

\section{Erratum to: Plant Cell Tiss Organ Cult \\ DOI 10.1007/s11240-017-1301-9}

In the original publication, the concentration of abscisic acid mentioned in the Abstract and in the Materials and Methods was incorrect. It should have read $15 \mathrm{mg} \mathrm{l}^{-1}$.

The online version of the original article can be found under doi:10.1007/s11240-017-1301-9.

Yong-Eui Choi

yechoi@kangwon.ac.kr

1 Department of Forest Resources, College of Forest and Environmental Sciences, Kangwon National University, Chuncheon 24341, Republic of Korea 